\title{
A Study of Peri-Urban Areas as Sites for Understanding Urbanisation in Developing Countries: Using Nairobi Peri-Urban Areas as Base Case Study
}

\author{
Aggrey Daniel Maina Thuo \\ Department of Spatial Planning and Urban Management, Kenyatta University \\ P.O. Box 43844- 00200- Nairobi Kenya
}

\begin{abstract}
The process of urbanization majorly drives economic, social and physical change in developing countries such as those in Sub-Saharan Africa. Planet's future is an urban one and that the largest and fastest growing cities are primarily in developing countries. This rapid urban growth has led not only to an increasing demand for urban land, particularly for housing, but also for other various urban uses. The increasing demand for land is affecting peri-urban areas, where urban expansion is already encroaching into the agricultural lands and small villages. The conversion of agricultural land to urban uses is leading to rapid transformations in agricultural production, spatial structure, social structure, land ownership and land markets in the peri-urban areas. Despite the importance of the peri-urban areas, it is still less understood especially in the context of developing countries. This paper argues that the dynamics at work in the peri-urban areas have not been fully captured, as they are often not visible until physical land conversion actually begins or takes place. It is at the peri-urban areas however that we can best understand the process of today's urbanisation (especially in developing countries), land conversions and development, as well as the evolving conflicts over land uses. It is also in the fringe where there is an opportunity to manage urban growth patterns before they get imprinted on the landscape.
\end{abstract}

Keywords: Urbanisation, Peri-urban areas, Land

DOI: $10.7176 / \mathrm{DCS} / 10-10-05$

Publication date:October $31^{\text {st }} 2020$

\section{Introduction}

The process of urbanization is majorly drives economic, social and physical change in developing countries such as those in Sub-Saharan Africa (Pieterse 2008; Simon 2007, 301). Rakodi (1997, 1) argued that it is "almost a truism that the planet's future is an urban one and that the largest and fastest growing cities are primarily in developing countries." Aguilar and Ward (2003) indicated that rapid urban population growth has led not only to an increasing demand for urban land, particularly for housing, but also for other various urban uses. And that in many countries, the increasing demand for land is affecting peri-urban areass, where urban expansion is already encroaching into the agricultural lands and small villages.

Maconachie (2007), Masuda and Gavin (2006), Mbiba and Huchzermeyer (2002), Briggs and Yeboah (2001), Tacoli $(1999 ; 1998)$ and Browder et al., (1995) indicates that the conversion of agricultural land to urban uses is leading to rapid transformations in agricultural production, spatial structure, social structure, land ownership and land markets in the peri-urban areas. This paper argues that the dynamics at work in the peri-urban areas have not been fully captured, as they are often not visible until physical land conversion actually begins or takes place. It is at the peri-urban areas however that we can best understand the process of today's urbanisation (especially in developing countries), land conversions and development, as well as the evolving conflicts over land uses. It is also in the fringe where there is an opportunity to manage urban growth patterns before they get imprinted on the landscape.

Despite the importance of the peri-urban areas, Maconachie (2007), Simon et al., (2006: 7), Mbiba and Huchzermeyer (2002) and Audirac (1999) indicated that the area is still less understood especially in the context of developing countries. Among the reasons given for the relatively low number of studies of the peri-urban areas is the divisions of academic disciplines that focus centrally on areas that have either rural or urban issues at their heart. This rural/urban dichotomy does not promote a comprehensive discourse about the development occurring in the area where urban and rural areas meet. Also contributing to the lower number of studies is the conceptual and operational separation of urban and rural areas in planning theory and practice (Evans and Mabbit 1997). Additionally, the concept of urban sprawl, which seeks to explain the peri-urban areas areas, has also been cited as obscuring the complexity of cultural, environmental, economic and social forces at work in this space (Audirac 1999: 7).

Conceptually, this paper based on qualitative research approaches and using Nairobi peri-urban areas as a case study, is premised on an understanding that, no single theory can provide a full explanation on how different influences, factors and linkages of peri-urban areas urbanization can be established or understood. Therefore, an approach which stretches across the twin poles of structure and agency is needed. It thus follows that to understand 
various dimensions of this urbanization and the links among them, a conceptual framework that focuses on neoclassical, political economy, and structure and agency theoretical perspectives is adopted. Neo-classical and political economy theoretical perspectives could not provide insights into localised/individualised aspects of urbanisation such as the agency of the landholders, therefore in developing my argument, I further drew insights from Giddens' theory of structuration (Giddens 1984) to conceptualise how an actors' agency interacts with structural determinants of change to shape the conditions for urbanisation at the local level.

Insights from an actor-oriented approach (Long and Long 1989) were also borrowed to augment the idea of how people make choices and how those choices lead to the shift of the structures and activities of various institutions over time. It is the actions of the actors that illustrate how they exercise their agency within existing structures to address the circumstances that local and extra-local conditions are creating in their areas.

This paper further indicates that, different aspects of urbanisation in peri-urban areas interact in a contingent and recursive manner in the conversion of agricultural land to urban land uses (see Figure 1). The figure further indicates that many of the influences on urbanisation at the micro-level are not necessarily local but are a product of wider social, cultural, political and economic conditions that challenge the economic viability of agricultural enterprises.

This paper examines various conditions and drivers that influence urbanisation of the Nairobi peri-urban areas. It is based on the assertion that, to understand why urbanisation is taking place in the Nairobi peri-urban areas, it is necessary to focus not just on economic pressures on the land market, but also on the social, cultural, political and environmental changes that the proximity to the City and 'new' land uses are bringing to an area like Nairobiperi-urban areas (which are 'supposedly' agricultural). This paper also recognises that land use change in an urbanising context such as in the Nairobi peri-urban areas can be understood at different scales. The scales are related to site or situational aspects. According to Bentinck (2000: 96), "site refers to the physical and cultural characteristics, and attributes of a place..." while situation refers to "...the external relations of a locale."

This paper combines both attributes of land use conversion that are as a result of site and situational changes, while appreciating that it is hard to draw a line between what comes first or what leads to what (see Figure 1). Furthermore, it is not easy to separate these forces and any attempt here to classify them into various groups (subsections) is inherently problematic. Interdependent of site and situation-oriented conditions and drivers of urbanisation will become clear in the discussion that follows in the sub-sections below.

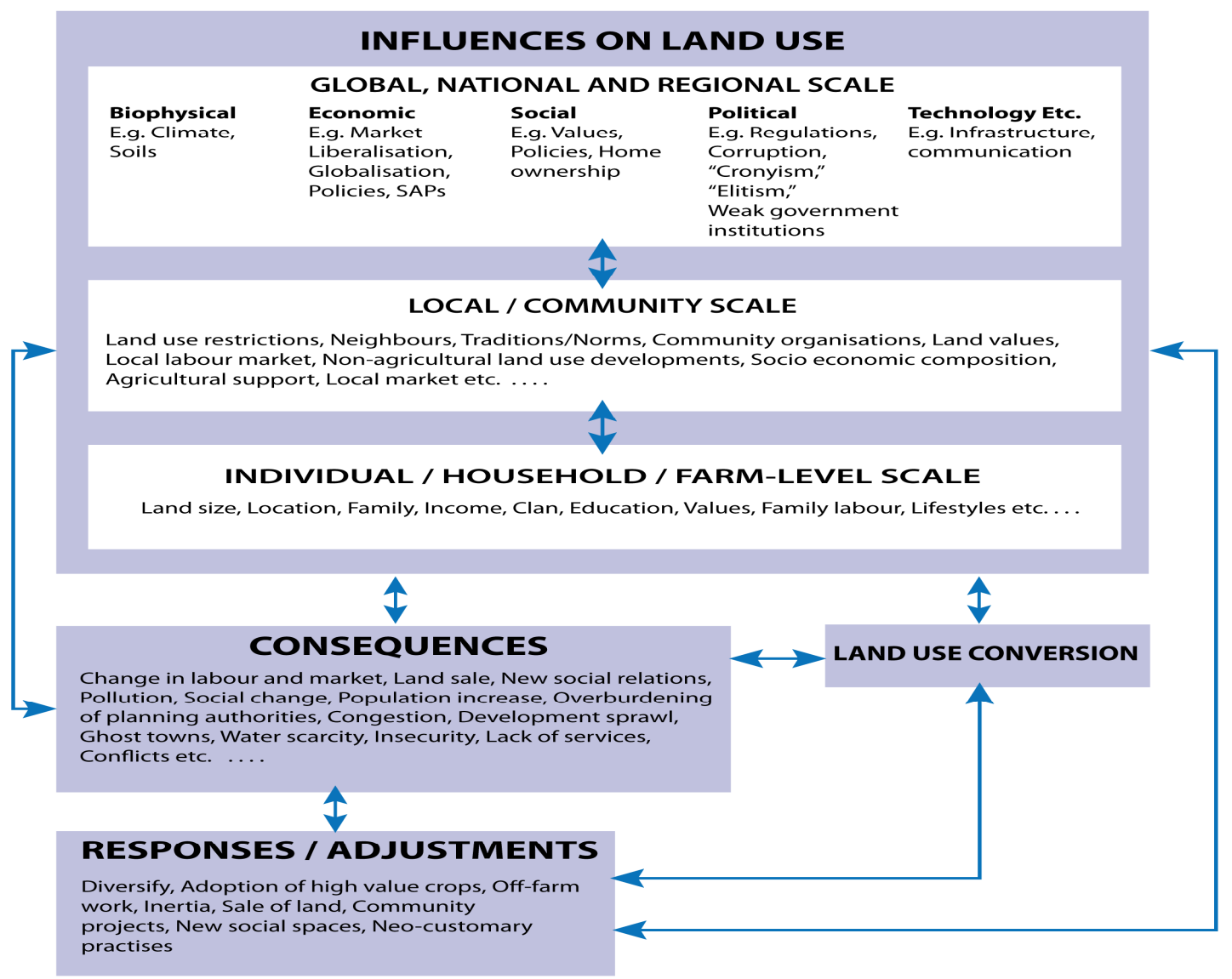

Figure 1: Schematic diagram of the complex links in land conversion in the Nairobi peri-urban areas (Adapted from Smithers and Johnson 2004). 


\section{Governance, planning and land use}

Lack of affordable housing due to high costs of land and non-provision of public housing in Nairobi City is making people search for housing in the peri-urban areas. This can partly be attributed to a colonial land ownership legacy that has not changed much since independence. Also, the City inherited colonial building codes, standards and regulations which were constraining and meant to restrict native Africans from permanently staying there. These factors created additional bureaucratic obstacles for those wishing to build formal houses particularly in incremental ways and using non-prescribed building materials within the City. In regard to land in the City, there are also problems in ascertaining ownership, particularly where land lease titles have elapsed and the political elite have taken advantage of the situation to illegally allocate themselves and or their cronies land which they have later sold to people using unofficial channels. The outcomes of these activities have resulted in a lack of transparency in land transactions within the City, further scaring potential homeowners away.

Besides land transactions being under the control of a restricted set of actors, there is also little or no control by local authorities when it comes to complying with urban planning requirements. This observation concurs with Pacione's (2009: 120) comments on African urbanisation that "more of the population have moved to the urban peripheries where ...official planning regulations are rarely enforced." The majority of the land in the Nairobi periurban areas is classified as agricultural and thus covered under sub-division schemes programme where the role of the planning authority is just advisory. This is in contrast to land use planning compliance requirements in the City, where (in absence of explicit urbanisation and housing policy and the vagueness of the land market) corruption and other non-civil behaviours (among the council officials and land dealers) take place. Such situations of policy, institutional and market failures align with Potts' (2004: 349) observations that "...social and political relations (whom you 'knew') could often affect access to urban (and rural) goods and services."

Satterthwaite (2006: 669) argued that "[i]t is not rapid urbanisation but the lack of attention to developing urban governance structures and economic stagnation that underpins most urban problems." Looking at his argument with reference to the Nairobiperi-urban areas, urbanisation is taking place in a situation of legal and policy ambiguity because of lack of explicit land and urbanisation policies for the whole of Kenya. This has led to legal and jurisdictional overlaps among institutions/departments involved in land use development control. This is also made worse by weak local authorities in the Nairobi peri-urban areas (which in most cases were initially designed to cater for rural and agricultural interests). These local authorities lack capacity and capabilities for managing rapid land developments taking place in the fringe which has resulted in delays in granting approvals to developers. Other than lack of capacity to enforce development control, there is also lack of information on which land use planning and control can be based. In this case, there is no planning framework to which decisions on plan approvals can be referenced. This has created apathy among Planning Officers who have to rely on the goodwill of the developers to 'do good' in the implementation of their proposed land development activities.

Multiple government institutions/departments (with separate goals and mandates on land) coupled with a lack of planning guidelines (such as Local Physical Development Plans) have created a jurisdictional vacuum (UNHabitat 2009: 7). This vacuum is being misused, especially by Land Board members, to grant approvals for the subdivision of agricultural land (though knowing it is meant for residential purposes) without seeking the advice from the Physical Planning Office. The ambiguities in responsibilities and jurisdiction are also promoting corruption among officers involved in land development approvals (see also similar observations by Simon (2008: 11). Even where attempts have been made to provide planning guidelines, there has been poor involvement of appropriate agencies and stakeholders thus denying such guidelines the legitimacy and widespread acceptance by the majority of the actors taking part in land use conversions. There is also political interference in land use planning and control which reduces effectiveness and operations of the Physical Planning Office in enforcing land use development control within the Nairobi.

Commenting on land issues in the peri-urban fringe, Simon (2008: 11) noted that:

... as is common in Africa and South and Southeast Asia, peri-urban land is held under some

form of communal tenure or state ownership, the chief, elders, village council, or local officials will usually preside over approaches by outsiders to acquire land.

In the Nairobiperi-urban areas, the control of land use is constrained by the existence of dual legal systems; customary and formal land ownership systems co-exist. Customary land use practices, such as sub-division of land for inheritance among family members, are predominant. With time this has led to fragmentation of landholdings into uneconomic parcels for agricultural purpose. When subdivision of land is done for residential family use, this leads to in situ urbanisation, where some areas of the Nairobi peri-urban areas have become densely settled without significant in-migration. Commenting on in situ growth, Pacione (2009: 466) noted that “...in situ population growth is producing densities that equal or surpass the widely accepted urban threshold of 400 persons per square kilometre." The average population density in the Nairobi peri-urban areas is 1,275 persons per square Kilometre which is more than three times Pacione's noted threshold. The in situ (quasi) urban settlements in the Nairobi periurban areas are, however, without an economic base and facilities for a self-supporting urban community.

In some areas where family members have been subdividing their ancestral land, struggling coffee growing 
companies have also been subdividing their estate among the members who then sell their plots or build rental housing blocks. There are also land owners who have subdivided their land parcels to cash-in or to avoid restrictive zoning regulations that are likely to be put in place as a result of the prospective boundary extension of Nairobi City. Landholders' awareness of the likelihood of implementation of zoning regulations once the Nairobi Metropolitan Aauthority comes into force was creating a condition of 'impermanence' for those still practicing large-scale farming in the Nairobiperi-urban areas. These observations align with Simon's (2008: 11) argument that "...peri-urban cultivation becomes more difficult and precarious when likelihood of land sale and urban development increase." Hence, when thinking of issues at peri-urban areas, one should be aware of the complex situations that interplay and influence the land use and planning activities of local actors.

\section{Income, investment, house prices and land use}

Commenting on urbanisation in cities of the developing countries, Satterthwaite (2006: 668) argued that: One of the reasons why urbanisation has been so rapid in many nations (in Africa and Asia) is because it began from such a small base, as the colonial powers kept down urban population by imposing restrictions on the rights of their national populations to live and work in urban centres.

Further, according to Pacione (2009: 6) "[d]emographic changes are among the most direct influences on urbanisation and urban change... [for example] in Third World countries expectations of improved living standards draw millions of migrants into cities." At independence, Kenya too saw an upsurge of urban population due to relaxed rural-urban migration policies. In regard to Nairobi City, in-migrants came to look for a better life and formal employment. Due to unavailability of formal jobs to employ the growing numbers of job seekers, a good number of people joined the informal employment sector. The number of those working in this sector has surpassed those in formal employment: an observation that echoes UN-Habitat (1996: 90) comment that "... the urban informal sector has become a powerful force for employment in virtually all African cities." The informal sector has become "a permanent part of urban economies..." (Rakodi 2006: 659) in cities such as Nairobi.

Potts (2004: 348) argued that "[i]n absence of a welfare sector, urban dwellers had to find some ways of getting by..." In the case of Nairobi City, for informal sector workers to safeguard their stay there, owning a house becomes a necessity. As Pacione (2009: 530) argued, the “... majority of low-income households in the Third World do not satisfy conventional criteria for mortgage finance... [because they are] unable to service the debt in terms of the amount and requirement for regular repayments..." Informal sector workers are also rarely eligible for mortgages because of their non-regular income and also their fear of erratic banks interest rates. Furthermore, although the option of owning a house within the City exists, it is fraught with constraints and thus makes these people fear the 'formal' strategies of owning a house. As a consequence, they find the Nairobi peri-urban areas a preferable site to build their houses. This aspect of migration from 'urban' to 'rural' in search for accommodation by City residents differs from "return migration" (Foeken and Owuor 2008, 1979; Oucho 1996: 91 \& 100) where people return to their home in rural areas because of retirement, retrenchment or through governments' efforts to reduce rural-urban imbalances.

Commenting on urbanisation in Eastern and Southern Africa, Potts (2004: 329) noted that:

...structural adjustment programmes (SAPs) and trade liberalisation have each in turn profoundly influenced urban growth patterns, urban service provision and the sectoral composition of urban economies with its vital corollaries: urban employment and income patterns.

Looking at the Kenya's situation in light of Potts' comments, Nairobi peri-urban areas study indicated that the era of SAPs and subsequent adoption of various neoliberal policies saw the liberalisation of export and import markets in Kenya. These created an emergent class of business people within a short span of time. However, due to reduced donor support for the national budgetary deficit, there was reduced investment in physical, social and technical infrastructure, necessary for the stimulation and growth of industrial and manufacturing sectors. Investment in security, roads, water and electricity generation also became inadequate even more so in those areas experiencing fastest growth such as the peri-urban areas. This meant that 'new' businesswomen and men did not have many options on which to re-invest their business proceeds. Land and urban housing became the easy (if not the only) option for them to invest their resources. The absence of public housing provision encouraged private sector investment. Nairobi peri-urban areas showed that, given the constraints that pertain to the land market and also bureaucratic systems operating within the City, the Nairobi peri-urban areas became a preferred site for these actor-investors, who bought plots of land for construction of self-built houses, rental apartments or just buying parcels of land for speculation purposes.

Maconachie (2007: 12) noted that in Kano, Nigeria, livelihoods have “...become increasingly challenged by declining commodity prices, the burden of taxation, and the erosion of communal labour structures, which had forced a 'peasant reproduction squeeze'...". In the Nairobi peri-urban areas, there has been reduced income from agriculture which has also been occasioned by the implementation of SAPs that saw costs of inputs increasing 
against reduced earnings from farm products. Reduced earnings together with rising cost of labour have seriously affected the continuation of farming as an enterprise especially when faced with competition for land for residential purposes. Furthermore, reduced earnings from farming and the emergence of other land uses willing to pay high prices for the same land leads to the cost of land rising beyond the exchange price between farmer to farmer. Existing farmers are thus denied an opportunity to expand their parcels of land through buying of additional land from neighbours.

Simon (2008: 11) argued that "...greater proximity and accessibility to enlarged urban market can create - at least for a time until the arrival of a concrete carpet -new opportunities to intensify peri-urban agriculture and to specialise in higher value horticultural crops...". In the Nairobi peri-urban areas, the decline in coffee farming as a result of global prices and reduced farm sizes made many farmers abandon coffee cultivation in favour of fast growing and high value crops such as fruits and vegetables, and zero grazing of dairy cows to take advantage of their proximity to the City and also the ready market in their midst. Compared to coffee, zero grazing and horticultural farming do not require huge parcels of land and thus can be supported on a small piece of land. This reduces the need for big parcels of land and thereby releases excess land for conversion into rental housing units or for sale for urban purposes. This is a case of a City benefitting from "world agrarian crisis" (Davis 2006: 16). This observation points to the fact that the value of agriculture per se has not declined in absolute terms but landholders have taken advantage of the prevailing situation to re-orient their land production system.

Responses from indigenous landholding and non-landholding groups to opportunities created by in-migration (such as operating food kiosks and provision of other services along the major roads within the Nairobi peri-urban areas) have made the area attractive to City residents. These services were initially restricted to designated market centres but are currently spreading in different parts of the area, especially along major roads. Decentralised shopping and services coupled with availability of rental houses have increased the demand for land for residential housing particularly to urban workers.

High demand for land for construction of residential housing, given that land in the Nairobi peri-urban areas is more expensive than in most rural areas in the country, has encouraged ingenuity among landholders who convert portions of their land to residential housing purposes or sell whole or parts of their land in order to buy bigger but cheap parcels of land elsewhere in rural settings. Similar observations were made by Binns and Maconachie (2006: 217) in Kano where “... high peri-urban real estate prices have enticed farmers to liquidate their assets and purchase farmland in less expensive, more peripheral, areas." This tendency has further jeopardised sustainable farming in the Nairobi peri-urban areas especially having in mind that even those who chose to continue farming are negatively affected by the consequences of residential land use. The cost of living, in terms of services and commodities, has also become relatively high for those who still farm in the Nairobi periurban areas. The same cost of living impacts are also experienced by non-landholding groups such as farm labourers. These costs are attributed to the emergence of newcomers with greater purchasing power than indigenous group.

Simon (2008: 15) argued that "[a]lthough historically, PUI [peri-urban interface] residents have been relatively and/or absolutely poor, outmigration of wealthier people to construct large houses on cheaper land in the PUI often changes the socioeconomic profile of residents...”. Increased population through natural growth and immigration into the Nairobi peri-urban areas is creating new income opportunities. This is more so given that newcomers are better off economically than the indigenous population and thus they have high purchasing power for services and goods. Simon et al., (2004: 243) in their study in Kumasi, Ghana observed that "average condition of zongo [newcomers] ...is better than [that] of the indigenes." The new income opportunities in the Nairobi periurban areas are in service sectors such as repairs, the construction sector and the local market for farm produce. Newcomers are also more exposed to the 'outside world' than locals and thus contact with them is bringing in new awareness of income opportunities outside the Nairobi peri-urban areas. When these factors affect traditional farming landholders (whose earning has been on the decline), the result has been the abandonment of farming as a major source of income, thus land is likely to be sold or converted to non-farm uses. Similar phenomena were cited by Binns and Maconachie in Kano, Nigeria. They reported that "[a]s a growing percentage of peri-urban land has come under the control of [urban] developers; farming has become increasingly difficult for those who continue cultivation" (2006: 217).

Simon (2008: 14) further noted that "[a] common feature of peri-urban interfaces in poor countries is the diversity of livelihood activities required by individuals and households in order to spread risk and gain adequate incomes." In the Nairobi peri-urban areas, there are notable transitions from traditional farming by landholders to other modes of farming or multiple livelihood activities jobs (as a result of conditions/factors making agriculture not economically viable), although not without hardships. Hardships notwithstanding, there are landholders who are able to diversify to other sources of income such as taking on a non-farm job locally or in the City to complement the dwindling earning from the traditional farming. Those who quit/convert from traditional farming and/or are not able to get a foothold in non-farm jobs often experience hardships. This is because of lack of skills and capital for the adoption of new agricultural production modes and a lack of money to cater for immediate and 
urgent needs for food, school fees and medications, among others. This observation compares with Cambodia where 60 percent of peasants "who sell their land... are forced to do so by medical debts" (Davis 2006: 15).

There are also farmers with loans acquired for coffee production but who have to nevertheless repay the loan even after ceasing coffee farming. During this transition period, landholders are likely to sell portions of their land to meet their immediate needs. These immediacy problems are encountered by a number of landholders in the transition period and those with loans are often the first group to sell portions of their land. Some landholders, due to their unpreparedness for this transition, have progressively cut portions of their land for sale until at the end they are left with no land at all and they become landless and/or destitute (Also similar observations by Simon 2008: 11).

The inability of some landholders to adapt to changes in their surrounding by finding innovative ways of farming against dwindling land size in a semi-rural fringe calls one to question observations by Boserup (1965) and Mortimore $(1993 ; 1975)$ that smallholder farmers are able to respond to pressures by use of various forms of innovation.

\section{Labour transformations and land use}

Arterial roads from Nairobi City to other parts of the country pass through the Nairobi peri-urban areas. This has made many areas of the Nairobi peri-urban areas easy to access by use of public transport. This was particularly enhanced by the liberalisation of the public transport sector within Nairobi and the surrounding areas, which reduced costs and time of travel for those seeking to stay outside the City. A sizeable number of new migrants also own private cars hence finding it easy to buy land on areas away from major roads and thus leading to further land conversions.

The City has also affected labour within the Nairobi peri-urban areas in that there exists steady jobs against that of the agricultural sector which are mostly seasonal (traditionally dependent on coffee farming). In addition, the wages from non-farm employment in Nairobi City is higher compared to that from farm labour. There is also a negative attitude towards farm labour as a source of employment and livelihood. The attitude is reproduced through an education system that devalues farm jobs in favour of 'white collar' jobs, thus shunning farming jobs in favour of urban-based employment. The shunning of farm jobs has led to lack of adequate labour which consequently has raised the level of farm work wages especially during the peak seasons, such as harvesting. This has further jeopardised the position of agriculture especially when faced by other land uses competing for the same land in the Nairobi peri-urban areas. The shortage of labour is also an outcome of high incidences of HIV/AIDS, which according to Pacione (2009: 564) has contributed "to the Sub-Saharan 'urban penalty'." Due to illness, a good number of men and women who are affected and infected are not able to optimally contribute their labour in the agricultural sector (which in most cases, is labour intensive).

\section{Changing social organisation and the community}

Social and cultural influences from the City and also from the migrants have affected smallholders' farming system in the Nairobi peri-urban areas. These influences are creating intergenerational conflicts, where cooperation among household members, which is vital for the supply of non-paid family farm labour, is breaking down. Lack of nonpaid family labour is making the smallholding farming system (which thrives on such input) to be economically unsustainable for many farming households. This is due to the increased farm operation costs against dwindling income from agriculture, and thus, most of such farmers prefer to subdivide sections of their land for sale or they themselves construct rental houses. There are however those who have stuck with their parcels of land due to cultural attachments and this explains why there is patchy residential development in the Nairobi peri-urban areas. The cultural attachment to family land compares with an observation in Accra, Ghana that "land belongs to a vast family of which many are dead, few are living and countless numbers are still unborn" (Ollenu 1962 in Gough and Yankson 2006: 199) and therefore cannot be sold outright.

Because of inadequate housing in the City and an unstable urban land market, the Nairobi peri-urban areas has become an attractive site for those in need of land for housing. Here the land (which is mostly owned through the Mbari [clan] system) has been targeted due to its proximity to the City and the flexibility that is afforded by actors' personalised relations around land transactions. Under the Mbari system, locally specific social norms and systems of trust operate in effecting land sales and transfers. These local practices are based on locally embedded systems and are widely regarded and accepted by community members and even by non-community members.

As a result of widespread acceptance of local land transaction practices and their personalised nature, land buyers are able to acquire land through instalments and the incremental building of the houses is undertaken as new land buyers pay the remaining instalments. Imperfect land markets within the City have thus become a driving force in shaping land use in the Nairobi peri-urban areas as it compels actors to adopt strategies that are outside formal mechanisms to obtain land for housing. Informal mechanisms are thus more trusted and reliable than formal regulatory and planning systems that are operating in a situation of market uncertainties and, policy and legal ambiguities. While commenting on urban land issues on Anglophone Sub-Saharan Africa, Rakodi (2005: 5) noted 
that such trust exists because land transactions are “...witnessed (by local leaders, neighbours etc) and the validity of [such transactions] is generally respected by other actors in land delivery process..."

Further, commenting on the impact of urbanisation on kinship networks and other traditional forms of social support in Africa, Rakodi (2005: 50) noted that:

Urbanisation has commonly alarmed social commentators, because of its perceived effects ...

It is often asserted that social organisations such as kinship networks are breaking down, harming the socialisation of children into prevailing social norms and family support networks.

Entry of newcomers who are individual-oriented rather than communal-oriented has complicated local settings in the Nairobi peri-urban areas. They are bringing new challenges to existing social and institutional structures: typically crime and prostitution (see Figure1). Newcomers also have little attachment to customary values which discourage individual goal seeking in favour of communal pursuits. Non-alignment to customary norms allows newcomers to treat land (which is cultural and symbolic good to the indigenous group) like any other commodity that can be traded in the market. The newcomers' values are slowly being transmitted to the indigenous group (especially the youths) who see them as representing a more progressive system than their own. This is leading to breakdown in social relations and cooperation in a hitherto closely-knit semi-rural society. Once this happens young people lose foothold in their families which makes them vulnerable to vices such as crime and prostitution, which lead to early deaths and high incidences of HIV/AIDS.

Furthermore, other than losing family connections, young people have no attachment to ancestral land as a source of employment through agriculture and thus increased incidences of heirs (though many are not adequately prepared to fully participate in urban economy) selling their inherited parcels of land once parents die. In this way, agricultural land is replaced through subdivision for residential land purposes.

The presence of non-indigenous groups and also the need to accommodate changes in the Nairobi peri-urban areas has led to emergence of 'new' spaces of interaction and groups which are not tied to customary norms of the people, such as faith-and other interest-based groups (see Figure 1). Although this is a positive move especially in mobilisation of local resources for community good, it is leading to a breakdown of social ties, customary institutions and norms. These institutions, ties and norms are necessary in safeguarding family and communal land and resources in it. Their breakage is thus leading to rapidly increasing land conversions in the area. Besides the 'new' initiatives (which are meant to accommodate changes and the entrance of new group of residents) are serving as awareness forums for the young people of circumstances that are unfolding in their surroundings. This awareness to a large extent serves to prepare their participation in a changing environment and hence further undermining their attachment to land for farming.

Pacione (2009: 118) argued that "[a]s the national and urban economies stagnate in absolute terms and urban population continues to grow... the resources needed for roads, sewers, water systems, schools, housing and hospitals cannot keep up with demand." In the Nairobi peri-urban areas, the lack of involvement of planning authorities in the fringe land development and their poor revenue bases has led to under-investment in physical, social and technical infrastructure. Among the missing social infrastructure is provision of security by the Police Department. This, together with other problems, has led to increased crime. Increase in crime without an assurance of police protection has contributed to community-led initiatives in provision of security. This is done either through vigilante groups or engagement of formal and informal security guards. These individual and communal efforts to enhance security in the Nairobi peri-urban areas have to some extent led to the removal of the 'insecurity' tag which has long been synonymous with the Nairobi peri-urban areas. This can partly explain the upsurge in demand for residential housing in the fringe and thus potentially further jeopardising the position of agriculture in relation to land. This aligns with what Giddens (1984: 14) referred to "consequences... unintended by those who engage in those activities."

Commenting on the level of service provision in Sub-Saharan African cities Rakodi (2005: 62) argued that: There is nothing unusual in deficiencies of urban water supply... However, even in cities where the main piped supply has broken down or failed to expand to serve new areas...alternative arrangements have evolved, enabling cities to survive despite the breakdown of large scale reticulated supply systems.

In the Nairobi peri-urban areas, community based initiatives and other private sector service providers have taken over provision of other services such as water, waste disposal, dispute resolution and arbitration to residents. Although their level of service may not be excellent, these community-led services provision (with some reinforcement from NGOs and local authorities) is making the Nairobi peri-urban areas more 'habitable' inevitably leading to more people moving in to look for residential housing. However, Neuwirth (2005: 97), commenting on community-led initiatives, observed that "[d]espite the great love residents have for their community...things do not look promising..." This is because of mixed signals they receive from the government pertaining to the legal status of their settlements. 


\section{Consequences of land conversions and local environment}

While land in the Nairobi peri-urban areas continues to be converted from agriculture to residential uses, this process is affecting on-going farming for remaining farmers. During the rainy seasons soil from building sites is washed into water bodies where it causes siltation of dams and river channels. Siltation is causing flooding on river valleys and thus affects those still practising small-scale horticultural farming. Flooding is also caused by the reduced storm water ground infiltration due to the increased paved surface area. This, together with excess pressure on land (as result of intensive farming due to land shortage) is affecting farming in the area by causing soil erosion which is washing away top soils that are suitable for crops cultivation. Mining of top-soil for sale to those growing flowers, and building stone quarries are also reducing the amount of land available for farming.

Increased population density with little investment in services and infrastructure has led to problems related to poor waste disposal. Waste disposal problems are reducing the viability of agricultural enterprise in the affected areas, with similar observations are reported in Jakarta by Pacione (2009: 552). Management of liquid waste is posing a great threat to continued farming. This is because the waste is dumped into open ground especially in isolated farming areas or into river channels. This observation underscores Pacione's (2009: 550) statement that "[m] any cities in Asia and Africa have no sewers, and most human excrement and waste-water ends up untreated in watercourses, gullies and ditches." This is jeopardising the use of shallow wells and rivers - which Pacione (2009: 548) referred to as "little more than open sewers..."- as source of portable water. Irrigation of horticultural crops, such as vegetables on the river valleys, using surface water is also threatened due to faecal contamination from dumped human wastes. Binns and Maconachie (2006: 224) also made similar observation in Kano that "[i]ncreasing water pollution is ...a key problem in peri-urban Kano. Of particular threat to lowland irrigation crops..."

Commenting on land issues in the peri-urban areas of Colombo, Dayaratne and Samarawickrama (2003: 102) noted that "[c]ommunities are divided, with outsiders and insiders unable to build relationships and coherent communities." In the Nairobi peri-urban areas, especially in areas where farming and residential land uses coexist, conflicts are now manifest. These and other factors are seriously affecting continued farming as a viable enterprise in the fringe.

\section{Local changes and landholders' responses}

Land conversions are producing intended and unintended consequences in the Nairobi peri-urban areas. These consequences are leading to change in social, cultural, environmental and economic aspects of the fringe. Actors in land use are however not passively accepting their fate as victims of land conversions but instead they have been routinely monitoring local and extra-local circumstances affecting their surroundings. They have evolved varieties of local/human-level responses that enable them live in this rapidly changing environment. Their responses have created acknowledged and unacknowledged conditions that affect local land uses. Actions resulting from their responses are unintentionally creating enabling conditions for further land conversions either through making hitherto unfavourable areas for settlement favourable or creating more obstacles for continuation of viable agricultural activities. It then follows that land use conversions in the Nairobi peri-urban areas are a result of both the actions of landholders and outcomes of such actions. This observation accords with Pacione's (2009: 11) argument that "[1] ocal contexts...exert a powerful influence on (peri-urban areas) urban change." Simon (2008: 13), however, argued that "...the poorest households and members of the community, who are least able to resist the changes or to access alternative resources or livelihood activities, are most vulnerable."

\section{Conclusion}

This paper has pointed to a number of powerful conditions/factors operating on broader scales in determining what it is possible to do at the level for the individual landholder in respect to land use. Individual and social responses to land use conversions follow from changing economic, social, cultural and environmental conditions mediated through institutional factors. This does not deny that landholders have agency, but it is important to note that their agency is limited or strongly constrained by structural factors/conditions that are beyond their knowledge repertoire or control. Such conditions include land and housing market failure, lack of urbanisation and land policies, weak societal and governmental institutions, SAPs, new economic opportunities linked to the cities, social and personal characteristics, and environmental changes, among others. Collective and individual responses to such structural conditions reshape effects of drivers of land conversions differently thus leading to variations in land use decisions within different areas of theperi-urban areass. These variations are however affecting agricultural activities in the area especially if a substantial number of landholders chose to convert/sell their land for residential purposes.

\section{References}

Aguilar, A. and Ward, P. (2003). Globalization, regional development and mega-city expansion in Latin America: Analysing Mexico city's peri-urban Hinterland. Cities 20(1). 
Audirac, I. (1999). Unsettled views about the fringe: Rural-urban or urban-rural frontiers? In Furuseth, O.J. and Lapping, M.B., editors, Contested countryside: The rural urban fringe in North America, Aldershot: Ashgate, 7-32.

Bentinck, J.V. (2000). Unruly urbanisation on Delhi's fringe: Changing patterns of land use and livelihood. Nederlandse geografische studies (Netherlands).

Binns, T. and Maconachie, R. (2006). Re-evaluating people-environment relationships at the rural-Urban interface: How sustainable is the peri-urban zone in Kano, Northern Nigeria? The Peri-urban Interface: Approaches to sustainable natural and human resource use, 211.

Boserup, E. 1965: The conditions of economic growth. George Allen \& Unwin, London.

Browder, J.O., Bohland, J.R. and Scarpaci, J.L. (1995). Patterns of development on the metropolitan fringe: Urban fringe expansion in Bangkok, Jakarta, and Santiago. Journal of the American Planning Association 61(3), 310-327.

Dayaratne, R. and Samarawickrama, R. (2003). Empowering communities in the peri-urban areas of Colombo. Environment and Urbanization 15(1), 101.

Foeken, D.W.J. and Owuor, S.O. (2008). Farming as a livelihood source for the urban poor of Nakuru, Kenya. Geoforum 39(6), 1978-1990.

Furuseth, O.J. and Lapping, M.B. (1999).Contested countryside: The rural urban fringe in North America: Ashgate Publishing.

Giddens, A. (1984). The constitution of society: Outline of the theory of structuration. Cambridge: Polity Press.

Gough, K. and Yankson, P. (2006). Conflict and cooperation in environmental management in peri-urban Accra, Ghana. The peri-urban interface: Approaches to sustainable natural and human resource use, 196.

Huchzermeyer, M. (2008). Slum upgrading in Nairobi within the Housing and Basic Services Market: A Housing Rights Concern. Journal of Asian and African Studies 43(1), 19.

Long, N. and Long, A. (1992). Battlefields of knowledge: The interlocking of theory and practice in social research and development. Routledge.

Davis (2006).Planet of slums: Verso Books. London.

Maconachie, R. (2007). Urban growth and land degradation in developing cities: Change and challenges in Kano, Nigeria. Aldershot: Ashgate.

Mbiba, B. and Huchzermeyer, M. (2002). Contentious development: Peri-urban studies in sub-Saharan Africa. Progress in Development Studies 2(2), 113-131.

Mortimore, M. (1975). Peri-urban pressures. The population factor in African studies, 189-305.

Mortimore, M. (1993). Northern Nigeria: Land transformation under agricultural intensification. Population and Land Use in Developing Countries, 42-69.

Pacione, M. (2009).Urban geography: A global perspective. New York: Routledge.

Potts, D. (2004). Regional urbanization and urban livelihoods in the context of globalization. In Potts, D. and Bowyer-Bower, T., editors, Eastern and Southern Africa: Development challenges in a volatile region, Essex: Pearson Education Limited, 328-368.

Rakodi, C. (1997). Global forces, urban change and urban management in Africa. In The Urban Challenge in Africa: Growth and Management of its Large Cities, Tokyo: United Nations University Press, p 17-73.

Rakodi, C. (2005). The urban challenge in Africa. In Keiner, M., Koll-Schretzenmayr, M. and Schmid, W.A., editors, Managing urban futures: Sustainability and urban growth in developing countries: Ashgate Publishing, Ltd.

Rakodi, C. (2006). Urban livelihoods. In Clark, D., editor, The Elgar companion to development studies, Cheltenham: Edward Elgar Publishing.

Satterthwaite, D. (2006). Urbanisation and third world cities. In Clark, D., editor, The Elgar companion to development studies, Cheltenham: Edward Elgar Publishing.

Simon, D. (1997). Development reconsidered: New directions in development thinking. Geografiska Annaler. Series B. Human Geography, 183-201.

Simon, D. (2007). Urbanisation and global environmental change: New intergenerational challenges. International Journal of Green Economics 1(3), 299-306.

Simon, D. (2008). Urban environments: Issues on the peri-urban fringe. Annual Review of Environment and Resources 33, 11.11-11.19.

Simon, D., McGregor, D. and Nsiah-Gyabaah, K. (2004). The changing urban-rural interface of African cities: Definitional issues and an application to Kumasi, Ghana. Environment and Urbanization 16(2), 235.

Simon, D., McGregor, D.G. and Thompson, D. (2006). Contemporary perspectives on the peri-urban zones of cities in developing areas. In McGregor, D.G., Simon, D. And Thompson, D., editors, The peri-urban interface: Approaches to sustainable natural and human resource use, London: Earthscan.

Tacoli, C. (1998). Bridging the divide: Rural-urban interactions and livelihood strategies. Gatekeeper SeriesIIED/UCL London Environmental Economics Centre Development (United Kingdom). 
Tacoli, C. (1998). Rural-urban interactions: A guide to the literature. Environment and Urbanization 10, 147-166. Tacoli, C. (1999). Understanding the opportunities and constraints for low-income groups in the peri-urban interface: The contribution of livelihood frameworks. Paper produced for the research project on Strategic Environmental Planning and Management for the Peri-Urban Interface Research Project.

Tacoli, C. (2002). Changing rural-urban interactions in the Sub-Saharan Africa and their impact on livelihoods: A summary. London: Iied.

UN- Habitat. 1996: An urbanizing world: Global report on human settlements. Oxford: Oxford University Press.

UN- Habitat. 2009: Planning sustainable cities: Global report on human settlements. Nairobi, Kenya, UN-Habitat. 